Mikko Lappalainen, Juha Hulkkonen, Juho Inkinen,

Aleksi Kallio, Markus Koskela, Mona Lehtinen,

Mats Sjöberg, Osma Suominen ja Laxmana Yetukuri

\title{
Automaattisen sisällönkuvailun ohjelmiston rakentaminen - case Annif
}

Sisällönkuvailun automatisointiratkaisut ovat puhuttaneet kirjastomaailmassa viime vuosina, ja erilaisia kokeiluja on tehty niin Suomessa kuin maailmallakin. Kansalliskirjastossa kehitetty automaattisen sisällönkuvailun Annif-työkalu on herättänyt paljon mielenkiintoa monissa organisaatioissa ja kokemukset ensimmäisistä käyttöönotoista ovat olleet lupaavia. Mitä kehitysvalintoja Annifia rakennettaessa on tehty, ja minkälaisia haasteita kuvailun automatisointiin ylipäätään liittyy?

$\mathrm{T}$ ässä artikkelissa esitellään tekstiaineistojen automaattisen sisällönkuvailun ohjelmiston rakentamisen haasteita ja ratkaisuja erityisesti KAM-sektorin (kirjastot, arkistot ja museot) organisaatioiden näkökulmasta. Esimerkkinä käytetään Kansalliskirjastossa kehitettävää automaattisen sisällönkuvailun työkalua Annifia. Artikkeli pohjautuu selvitykseen, Sisällönkuvailun automatisoinnin haasteita ja ratkaisuja kulttuuriperintöorganisaatiossa (Hulkkonen ym. 202I), joka julkaistiin alkuvuodesta 202 I osana CsC:n, Kansalliskirjaston ja Kansallisarkiston yhteistä High-Performance Digitisation -hanketta.

\section{Sisällönkuvailun automatisoinnin lähtökohdat}

1.1 Manuaalinen, puoliautomaattinen ja automaattinen kuvailu

Sisällönkuvailun tarkoituksena on ilmaista kuvailtavan aineiston (esim. kirja, artikkeli, verkkosivu jne.) aihe aineiston löytämisen helpottamiseksi. Kirjastoissa ja muissa kulttuuriperintöalan organisaatioissa sisällönkuvailua on tehty pitkään ihmistyönä valmista asiasanastoa ja/tai muuta kontrolloitua sanastoa hyödyntäen, ja sisällönkuvailijoista on muodostunut oma ammattiryhmänsä ainakin isoimmissa kirjastoissa. Verkkomaailmassa sisällönkuvailua tehdään usein sivutyönä toisen pääasiallisen työn ohessa, kuten esimerkiksi toimittaja sisällönkuvailee kirjoittamansa artikkelin osana toimitustyötä. Tämä käyttäjäryhmien moninaisuus onkin hyvä huomioida automaattisen kuvailun ohjelmistoja ja palveluita suunniteltaessa, erityisesti silloin kun ajatuksena on tuottaa monissa erilaisissa ja erikokoisissa organisaatioissa hyödynnettäväksi soveltuva yleiskäyttöinen ohjelmisto.

Puoliautomaattisessa sisällönkuvailussa jokin järjestelmä antaa halutulle tekstille asiasanaehdotuksia, jotka käydään läpi ihmistyönä. Tarkoituksena on 
sujuvoittaa kuvailutyötä näillä pohjaehdotuksilla; ihmiselle jää kuitenkin päävastuu kuvailusta.

Täysin automaattisessa kuvailussa ohjelmiston/algoritmin tuottama kuvailu etenee sellaisenaan ilman ihmistarkistusta järjestelmän tietokantaan. Tässä menetelmässä sudenkuoppana on se, ettei asiasanoituksen laatu välttämättä vastaa ihmistyönä tehtyä. Positiivisena puolena kuitenkin voidaan nähdä se, että näin saatetaan saada edes jollain tasolla kuvailtua aineistoa, joka muuten jäisi kokonaan kuvailematta. Kuvailutyötä automatisoivilla ratkaisulla voidaan myös rikastaa olemassa olevaa metadataa.

Erilaisten dokumenttien sisältöä kuvaillaan monista eri lähtökohdista. Varsinainen asiasanoitus, koneellisesti tai ihmisvoimin, tehdään käyttötarkoitukseen sopivan kuvailusanaston perusteella, esimerkkinä vaikkapa Yleinen suomalainen ontologia Yso tai sen edeltäjä Yleinen suomalainen asiasanasto YsA. Tällä pyritään varmistamaan kuvailun yhteismitallisuutta ja aineiston löydettävyyttä.

Aineistoa voidaan myös kuvailla vapaammin - ja astetta subjektiivisemmin - käyttämättä kontrolloitua sanastoa tai laventamalla sanaston käyttöön liittyviä ohjeistuksia. Tällöin kuitenkin puhutaan ennemmin vaikkapa avainsanojen määrittämisestä tai aineiston "taggaamisesta".

\subsection{Sisällönkuvailun laadun mittaus}

Sisällönkuvailun laadun mittaaminen ei ole suoraviivainen tehtävä. On vai- keaa määrittää ehdottomat kriteerit laadukkaalle kuvailulle tai löytää jokin vertailukohta, joihin muiden samasta tekstistä tehtyjen kuvailujen oikeellisuutta voitaisiin verrata. Kuvailijoiden välillä, ja usein myös saman kuvailijan eri kerroilla tuottamien kuvailujen välillä, on harvoin kovin suurta yhdenmukaisuutta. Empiirisissä kokeissa eri ihmisten tuottamien kuvailujen yhdenmukaisuus on ollut 30-50\% (Medelyan 2009).

Laadun mittaamisesssa ja arvioinnissa voidaan hyödyntää esimerkiksi kuvailijajoukon keskinäistä samanmielisyyttä. Mitä enemmän yksittäinen kuvailu sisältää samoja asiasanoja kuin muut samasta tekstistä tehdyt kuvailut, sitä laadukkaampana tätä kuvailua voidaan pitää (ks. Rolling I98I). Tässä kuvailijaksi voidaan laskea algoritmitkin. Voidaan esimerkiksi laskea, kuinka monta samaa asiasanaa algoritmit ovat ehdottaneet dokumentille ja mitä ihmisten valitsemia asiasanoja jäi puuttumaan. Näin voidaan laskea tiedonhaun arvioinnista tuttuihin saantiin ja tarkkuuteen perustuvia tunnuslukuja, esim. F1-tunnusluku on saannin ja tarkkuuden harmoninen keskiarvo. Joskus arvioinnissa on myös otettava huomioon ehdotettujen asiasanojen järjestys, etenkin tilanteessa jossa oletetaan, että ensimmäiset asiasanat ovat tärkeimpiä. Mittarina esim. NDCG (Normalized Discounted Cumulative Gain) huomioi tämän.

Toinen tapa lähestyä sisällönkuvailun laadun arviointia on kysyä ihmisten mielipidettä ehdotetusta kuvailusta (ks. esim. Golub ym. 2016). Asiantuntijat 
tu automaattisen sisällönkuvailun järjestelmään. Toisessa vaihtoehdossa, joka ei vaadi järjestelmäintegraatiota, sisällönkuvailija syöttää tekstin suoraan automaattisen sisällönkuvailun järjestelmään esimerkiksi verkkolomakkeen kautta ja saa ehdotukset nähtäville kopioitavaksi varsinaiseen kuvailujärjestelmään. Tässäkin tapauksessa verkkolomake tukeutuu automaattisen sisällönkuvailun järjestelmän rajapintapalveluun. Annifin perustuva verkkolomake löytyy esimerkiksi Finto AI -palvelusta (kuva 2.).

Järjestelmän tuottamissa ehdotuksissa on toisinaan aiheita, jotka ovat dokumentin kannalta toissijaisia tai virheellisiä. Toisaalta jokin aivan keskeinen aihe voi puuttua ehdotuksesta. Tällöin sisällönkuvailija voi korjata kuvailuehdotusta poistamalla epärelevantteja aiheita ja lisäämällä uusia ennen kuin kuvailu tallennetaan kuvailujärjestelmään. Samalla kuvailujärjestelmä voi lähettää sekä alkuperäisen dokumentin että korjatun kuvailun automaattisen sisällönkuvailun järjestelmään, joka niiden perusteella päivittää mallia, korjaa toimintaansa ja kehittää ehdotuksia paremmiksi.

\subsection{Koneoppimismallien kouluttaminen}

$\mathrm{T}$ ekstin sisällönkuvailuun tarkoitetut koneoppimismallit ovat käytännössä aina sidoksissa tiettyyn sanastoon sekä luonnolliseen kieleen. Käytettävän sanaston ja kielen valinta tapahtuu luomalla "projekti", jossa märitellään joukko asetuksia, kuten käytettävä sanasto, kieli, algo- ritmi ja mahdolliset hyperparametrit eli koneoppimismallien rakenteeseen liittyvät asetukset.

Kun projekti on märitetty, se täytyy yleensä vielä kouluttaa esimerkkidokumenteilla. Kouluttamisessa luodaan projektin määritysten mukainen koneoppimismalli ja opetetaan se esimerkkidokumenttien avulla ennustamaan aiheita dokumenteille. Kouluttamisen jälkeen projekti on käyttövalmis.

Kouluttaminen tapahtuu syöttämällä koneoppimismallille korpus, joka koostuu joukosta etukäteen kuvailtuja dokumentteja. Kouluttamisen lopputulokseen vaikuttavat myös käytettävät esikäsittelytavat (esim. sanojen perusmuotoistaminen eli lemmatisointi) sekä koneoppimismallin hyperparametrit. Kouluttaminen saattaa olla raskasta ja vaatia paljon laskentaresursseja ja/tai RAM-muistia. Neuroverkkomallien kouluttamista nopeutetaan usein grafiikkasuorittimilla (GPU, graphics processing unit) suoritettavalla laskennalla, mutta siitä huolimatta mallin koulutus saattaa viedä tunteja tai jopa useita päiviä.

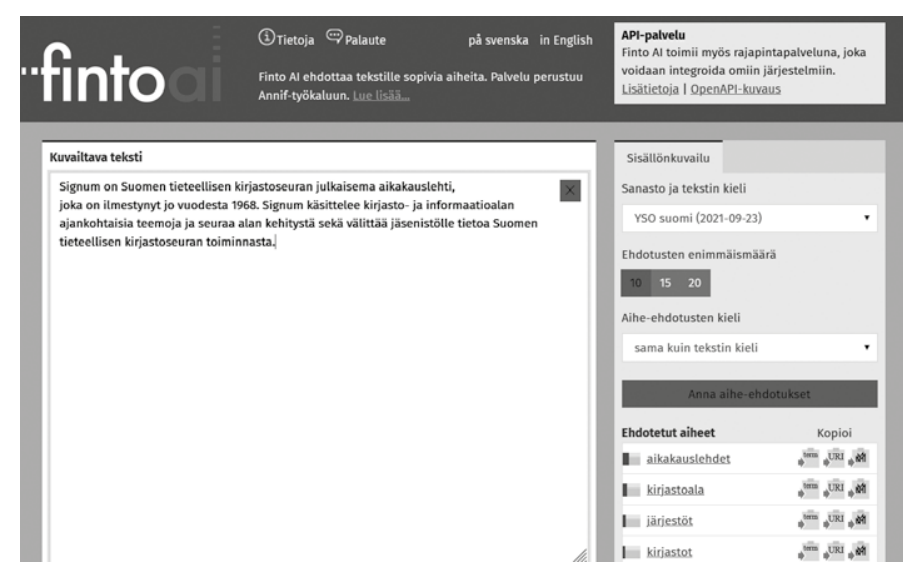

Kuva 2. Finto Al -palvelun Annifiin perustuva verkkolomake, johon käyttäjä voi syöttää haluamansa tekstin automaattisesti sisällönkuvailtavaksi. 
Projektien sisältämät koneoppimismallit voidaan kouluttaa uudelleen, jos siihen on riittävästi syitä. Muuttunut sanasto, parempi koulutusaineisto tai halu kokeilla uusia hyperparametreja voivat toimia perusteena. Sanastoa päivitettäessä haasteena on sanastoon lisättyjen uusien käsitteiden tunnistaminen. Useimmat koneoppimismallit pystyvät tunnistamaan vain niitä aiheita, jotka esiintyvät koulutusdatassa, joten ne eivät pysty ehdottamaan uudessa sanastoversiossa lisättyjä käsitteitä.

\subsection{Automaattinen laadun arviointi}

Kun projekti on koulutettu, sen tuottamien ehdotusten laatua voidaan arvioida tilastollisesti jo kuvailtuja dokumentteja vasten. Arvioinnin ajatuksena on tuottaa joukolle dokumentteja (testikorpus) aihe-ehdotukset ja verrata algoritmin antamia ehdotuksia aiemmin ihmistyönä tehtyihin kuvailuihin. On tärkeä varmistaa, että testikorpukseen sisältyviä dokumentteja ei ole käytetty projektin kouluttamisessa eli ne ovat algoritmin kannalta uusia, koska muuten algoritmi voi muistaa yksityiskohtia koulutusdokumenteista ja antaa siksi epärealistisen hyviä ehdotuksia.

Ehdotusten laatua arvioidaan tyypillisesti samankaltaisuusmittareilla kuten saanti, tarkkuus, FI-score ja NDCG. Jos arvioitu laatu ei tyydytä, voi ylläpitäjä kokeilla vaihtaa projektin asetuksia (esimerkiksi hyperparametrit) ja uudelleenkoulutuksen jälkeen arvioida laatua uudelleen, kunnes saavutettu laatu on riittävän hyvä.

\section{Käytettävien algoritmien valinta}

\subsection{Tekstin luokittelu sisällönkuvailussa}

Koneoppimisen näkökulmasta automaattiseen sisällönkuvailuun on useita erilaisia lähestymistapoja ja siihen voidaan soveltaa monia eri algoritmeja. Yleisesti ottaen sisällönkuvailua voidaan pitää moniluokkaisena tekstin luokittelutehtävänä, jossa jokaiselle syötetekstille poimitaan sitä parhaiten kuvaavat asiasanat käytössä olevasta sanastosta.

Sovellettaessa tekstin luokittelua sisällönkuvailuun, jokaista sanaston asiasanaa vastaa erillinen luokka eli asiasana-avaruudessa on yhtä monta ulottuvuutta kuin sanastossa on asiasanoja. Automaattinen sisällönkuvailu poikkeaa tavanomaisista koneoppimisen luokittelutehtävistä luokkien lukumäärän osalta. Koneoppimisessa on tyypillistä, että luokkia on suhteellisen vähän, yleensä korkeintaan joitakin kymmeniä tai satoja. Sisällönkuvailussa käytetyissä sanastoissa asiasanojen lukumäärä voi sen sijaan olla kymmeniätuhansia tai jopa enemmän. Esimerkiksi Wikipediassa käytetään yli miljoonaa kategoriaa sivujen luokitteluun. Tekstin luokittelua suureen määrään eri luokkia on viime vuosina tutkittu suhteellisen paljon. Siihen on kehitetty myös useita uusia menetelmiä, sillä sille on löydetty useita taloudellisesti merkittäviä sovelluksia.

Useat käytössä olevat algoritmit palauttavat myös asiasanoja vastaavat hyvyysarvot eli arviot asiasanojen rele- 
vanssista kyseessä olevalle syötetekstille. Näitä hyvyysarvoja voidaan käyttää asiasanojen rajoittamiseen esimerkiksi siten, että ainoastaan tiettyä kynnysarvoa korkeampia hyvyysarvoja vastaavat asiasanat otetaan huomioon, tai asiasanojen järjestämiseen relevanssin mukaiseen järjestykseen.

\subsection{Algoritmityypit}

Automaattisessa sisällönkuvailussa käytettyjä algoritmityyppejä ovat esimerkiksi:

- leksikaaliset algoritmit

- tiedonhakualgoritmit

- luokkakohtaiset luokittelualgoritmit

- puualgoritmit

- tiivistysalgoritmit

- hierarkkiset luokittelualgoritmit

- neuroverkot.

Eri algoritmityypit lähestyvät tehtävää eri näkökulmasta. Esimerkiksi tiedonhakualgoritmien tapauksessa sisällönkuvailutehtävä voidaan tulkita tiedonhakuongelmana, jossa kuvailtava syöteteksti vastaa hakukyselyä ja jokaista sanaston asiasanaa vastaa sitä varten laadittu asiasanaa kuvaileva dokumentti tai joukko dokumentteja. Puualgoritmit puolestaan perustuvat hajota ja hallitse -periaatteeseen, jossa alkuperäinen ongelma jaetaan yksinkertaisemmiksi osaongelmiksi ja joiden tuloksista alkuperäisen ongelman ratkaisu lopuksi koostetaan.

Annif hyödyntää tekstin kirjoitushetkellä pääasiassa leksikaalisia ja puualgoritmeja, mutta kokeiluja eri algoritmityyppien toimivuudesta tehdään jatkuvasti.
Algoritmityyppien rajat eivät ole tarkasti määriteltyjä, ja sisällönkuvailussa käytettävät menetelmät saattavatkin sisältää osia tai ominaisuuksia useista algoritmityypeistä. Algoritmeja voidaan myös yhdistää, ja parhaat tulokset saavutetaankin usein erilaisten algoritmien tuloksia yhdistelevillä (ensemble) malleilla. Annif tukee yksittäisten algoritmien käytön lisäksi yhdisteleviä malleja.

\section{Yhteenveto}

Sisällönkuvailua tehdään aineiston löydettävyyden parantamiseksi, eli tiedonhakijoita varten. Kuvailun automatisoinnilla pyritään helpottamaan ja sujuvoittamaan kuvailijan työtä ja saattamaan kuvailun piiriin aineistoja, jotka muuten saattaisivat jäädä kuvailematta. KAM-sektorilla kuvailutyötä tekevät esimerkiksi organisaatioiden tiedonhallinnan ammattilaiset, mutta kuvailua tehdään paljon myös ns. oman toimen ohella. Automaattisen kuvailun järjestelmiä rakennettaessa yhtenä haasteena onkin järjestelmää hyödyntävien kuvailijoiden heterogeeninen tausta, ja sitä kautta erilaiset tarpeet.

Kuvailua automatisoitaessa on tärkeää seurata ja mitata kuvailun laatua. Sisällönkuvailun laadun mittaus ei ole kuitenkaan suoraviivainen tehtävä, koska absoluuttisen oikeaa kuvailua on usein mahdotonta määritellä. Useissa tapauksissa voikin olla tarpeen hyödyntää erilaisia laatumittareita samanaikaisesti.

Annifin kaltaisen automaattisen sisällönkuvailun työkalun käyttöön- 
otossa lähtökohtana on sopivan kuvailusanaston valinta. Käytettävien koneoppimismallien opettamiseen tarvitaan valitulla sanastolla ihmistyönä kuvailtuja esimerkkidokumentteja. Sisällönkuvailupalvelun suunnittelussa tulee lisäksi ottaa huomioon käytettävien mallien käyttömahdollisuudet erilaisille aineistoille, koulutusaineistojen koko ja ylläpidon tarve.

Automaattiseen sisällönkuvailun ohjelmisto voi hyödyntää monia erilaisia algoritmeja, joiden lähestymistavat poikkeavat toisistaan. Parhaiden tulosten saavuttamiseksi onkin usein tarpeen yhdistellä eri tyyppisiä algoritmejä. Lopulta Annifin kaltainen ohjelmisto tulee tarjota käyttäjien hyödynnettäväksi mahdollisimman helpolla tavalla, esimerkiksi rajapintaintegraationa olemassa olevaan kuvailujärjestelmään.

\section{Lähteet}

Golub, K., Soergel D., Buchanan G., Tudhope D., Lykke M. \& Hiom D., 20 i6. A framework for evaluating automatic indexing or classification in the context of retrieval.

Journal of the Association for Information Science and Technology, 67(I): 3-16. https://doi.org/I0.1002/asi.23600

Hulkkonen, J., Inkinen J., Kallio A., Koskela M., Lappalainen M., Lehtinen M., Sjöberg M., Suominen O. \& Yetukuri L., 202 I. Sisällönkuvailun automatisoinnin haasteita ja ratkaisuja kulttuuriperintöorganisaatiossa. https://urn.fi/ URN:ISBN:978-95 I-5 I-7233-4

Medelyan, O., 2009. Human-competitive automatic topic indexing

(Doctoral dissertation, The University of Waikato). https://researchcommons.waikato.ac.nz/handle/I0289/3513

Rolling, L., I98 I. Indexing consistency, quality and efficiency. Information Processing \& Management, I7(2), 69-76. https://doi.org/10.10 I6/0306-4573(8I)90028-5

SuOMinen, O., 20I9. Annif: DIY automated subject indexing using multiple algorithms. LIBER Quarterly, 29(I), pp.I-25. DOI: http://doi.org/IO.I $8352 / \mathrm{lq} .10285$

Mikko Lappalainen Kansalliskirjasto mikko.lappalainen@helsinki.fi
JuHA HulKKonen

CSC - Tieteen tietotekniikan keskus juha.hulkkonen@csc.fi
JuHo InKInen

Kansalliskirjasto juho.inkinen@helsinki.fi

\section{Aleksi Kallio}

CSC - Tieteen tietotekniikan keskus aleksi.kallio@csc.fi

\section{Mats SJöBERG}

CSC - Tieteen tietotekniikan keskus mats.sjoberg@csc.fi
Mona Lehtinen

Kansalliskirjasto mona.lehtinen@helsinki.fi

Osma Suominen

Kansalliskirjasto osma.suominen@helsinki.fi
Markus KosKela

CSC - Tieteen tietotekniikan keskus markus.koskela@csc.fi

\section{Laxmana Yetukuri}

CSC - Tieteen tietotekniikan keskus laxmana.yetukuri@csc.fi 